\title{
Competition and Innovation in a Hostile Environment: How Jabhat Al-Nusra and Islamic State Moved to Twitter in 2013-2014
}

\section{Gunnar J. Weimann}

To cite this article: Gunnar J. Weimann (2019) Competition and Innovation in a Hostile Environment: How Jabhat Al-Nusra and Islamic State Moved to Twitter in 2013-2014, Studies in Conflict \& Terrorism, 42:1-2, 25-42, DOI: 10.1080/1057610X.2018.1513692

To link to this article: https://doi.org/10.1080/1057610X.2018.1513692

ช

(c) 2018 The Author(s). Published with license by Taylor and Francis Group, LLC

曲 Published online: 05 Nov 2018.

Submit your article to this journal $₫$

Џll Article views: 1028

Q View related articles ए

View Crossmark data ¿ 


\title{
Competition and Innovation in a Hostile Environment: How Jabhat Al-Nusra and Islamic State Moved to Twitter in 2013-2014
}

\section{Gunnar J. Weimann}

Institute of Security and Global Affairs, Leiden University, The Hague, The Netherlands

\begin{abstract}
Social media offer unprecedented opportunities to terrorist groups to spread their message and target specific audiences for indoctrination and recruitment. In 2013 and 2014, social media, in particular Twitter, overtook Internet forums as preferred space for jihadist propaganda. This article looks into Arabic statements by Jabhat alNusra, Islamic State and jihadist forum administrators and online activists to argue that, beside the easier use of social media and disruption and infiltration of the forums, the conflict between the jihadist groups accelerated the migration to social media and the building of a presence on Twitter that provided relative resilience to suspensions.
\end{abstract}

In early 2013, most analysts still agreed that, while increasing jihadist activities were detected on Twitter, a microblogging site launched in 2006, jihadist Internet forums would retain their central function in terrorist conversation and information distribution. ${ }^{1}$ Only one year later, Thomas Hegghammer felt that

Today forums remain important, but they seem to have been overtaken in 2013 by Facebook and Twitter as the preferred platform for internal multi-user communication. The jihadi migration to Facebook and Twitter has yet to be properly explained, but the breakdown in trust on the forums may have been a contributing factor. ${ }^{2}$

By late 2014, jihadist forums had either disappeared or lost much of their former relevance. Twitter had become a preferred platform not only for chatter among supporters but also for official releases by terrorist groups. ${ }^{3}$

Without doubt, the reasons for this shift are manifold. They include arrests of forum administrators and the frequent disruption of jihadist forums. Disruption of forums, despite all efforts to restore the platforms in the shortest time possible, resulted in a relative decrease of popularity after coming back online and accelerated the migration of members to either other forums, ${ }^{4}$ or ultimately to social media. In addition, the loss of trust on the part of terrorist organizations that supply the forums with material and, thus, their ability to serve as an authentic source for terrorist propaganda has been identified as a principal reason for the loss of relevance and the disappearance of forums. ${ }^{5}$ 
This article aims to shed light on another factor contributing to the loss of relevance of jihadist forums: the development of strategies by the so-called Islamic State (IS) and Jabhat al-Nusra to ensure a resilient presence on social media, in particular Twitter, which did not need authentication through jihadist forums. The two groups were not the first jihadist organizations to create official Twitter accounts, ${ }^{6}$ and other jihadist groups such as Al Qaeda in the Islamic Maghreb (AQIM) recognized the potential value of establishing themselves on Twitter during the same period of time. ${ }^{7}$ It is however argued that the competition between IS and Jabhat al-Nusra precipitated the migration from the forums to Twitter, as it forced the groups to build a resilient presence on the microblogging site despite increasing efforts by Twitter at disruption. In effect, the competition between IS and Jabhat al-Nusra stimulated innovation in terrorist communication in an increasingly hostile environment through the groups' need to gain ascendency over their opponents.

This study relies primarily on Arabic statements by the two groups and jihadist forum administrators to analyze the motivations of their actions. The analysis relies on social media posts, statements posted on social media and discussion forums, and documents released by the actors involved, which were collected during monitoring of official accounts in 2013 and 2014. The selection of the material was guided by the aim to trace the relationship between known actors, in particular IS, Jabhat al-Nusra, and prominent jihadist discussion forums. During the period of time under review, communication by these actors was still centralized to an extent that this methodology provided a comprehensive picture of their public statements. This notwithstanding, the approach has also limitations. Rather than telling a complete story, online statements provide punctual information on the declared motivations of the actors at a specific point in time. Entities representing particular actors disappear without explanation and others arise without defining exactly the relationship to former iterations. Rather than establishing a continuity of the actors involved, the sources allow identifying dynamics and trends.

The period under review was one of turmoil. In early April 2013, the leader of the Islamic State of Iraq (ISI), Abubakr al-Baghdadi, announced that Jabhat al-Nusra was nothing but an extension of the ISI in Syria. ISI and Jabhat al-Nusra would merge under the new name of Islamic State in Iraq and the Levant (ISIL). In an immediate reaction, Jabhat al-Nusra's leader Abu Muhammad al-Jawlani rejected the merger and declared his group to be an independent member of the Al Qaeda network responsible directly to $\mathrm{Al}$ Qaeda's nominal head Ayman al-Zawahiri. Al-Zawahiri ordered ISI to restrict its activities to Iraq and leave Syria to Jabhat al-Nusra, but by mid-2013, all mediation efforts by the Al Qaeda leadership had failed. The mediator appointed by al-Zawahiri was killed in an ISIL suicide attack; and ISIL rejected the orders given by al-Zawahiri. ${ }^{8}$ In 2013 , tensions between the factions increased gradually on the ground, as they tried to assert themselves in the face of their competitors. The same was happening on the Internet, which illustrates the importance attached to the online sphere by jihadist groups.

\section{A Jihadist Online Infrastructure}

Al Qaeda recognized early the possibilities that the Internet provided for disseminating propaganda messages, bypassing the state-controlled media in many Arab 
countries, such as Saudi Arabia. Al Qaeda leaders felt that they were suffering a "media siege," which was meant to prevent them from reaching out to the Muslim masses. ${ }^{9}$ Exploiting the possibilities offered by the Internet required special skills and dedication to keep pace with new technologies and counterattacks on the group's online presence. This created opportunities for supporters with the necessary skill set to provide services to jihadist groups. Al Qaeda and other groups have valued these efforts and incorporated them in jihadist ideology under the label of "media jihad" (al-jihad al-i'lami), which means that the spiritual reward of these activities is equaled to participation in fighting. Following the death of Osama bin Laden in May 2011, for example, the al-Fajr Media Centre (markaz al-fajr lil-ilam, "dawn media center") called the Internet a "battlefield for jihad" and appealed to all jihadist sympathizers to be "media mujahidin." 10

In an effort to become independent from mass media, such as al-Jazeera, Al Qaeda and other groups created specific brands for propaganda releases, most prominently alSahab Media, which, among other productions, has been in charge of publishing messages by Al Qaeda's central leadership. Creating a name, logo, and corporate design served to distinguish official propaganda productions from surrounding media and Internet content and create an impression of trustworthiness. It, thus, helped to authenticate original content issued by the groups.

After static websites of $\mathrm{Al}$ Qaeda and other terrorist organizations had been exposed to repeated attacks, jihadist forums, containing disclaimers that shifted legal responsibility for content from administrators to users, gained ascendency. The main jihadist forums appear to have considered themselves as independent initiatives supporting the global jihadist movement, rather than supporters of a specific group. Their vocation has been to provide a stage for members of the global movement from different conflict zones. ${ }^{11}$ Nevertheless, in case they were accepted by Al Qaeda's leadership as trusted distributors of their message, they were engaged in a relationship that demanded submission and acceptance of a hierarchy that ultimately depended on the Al Qaeda central leadership. ${ }^{12}$

$\mathrm{Al}$ Qaeda's instrument to control the forums was the al-Fajr Media Centre. Established in 2006, it provided the forums with original propaganda material from jihadist groups within the Al Qaeda network. For both jihadist groups and forums, adherence to the network controlled by al-Fajr Media was a sign of acceptance as part of the global jihadist movement and a "proof of authenticity" of the message. ${ }^{13}$ With regard to the forums, al-Fajr Media played a coordinating role, serving, for example, as an instance to which forum administrators could appeal in case of dispute. ${ }^{14}$ Al-Fajr Media also provided technical support to jihadist forums to remain online in the face of attacks. ${ }^{15}$ The administrators of the Ansar al-Mujahidin Network, for example, had no doubt that al-Fajr Media was directly linked to the Al Qaeda leadership, probably in the person of Atiyatullah al-Libi, who was killed in a drone strike in North Waziristan in August 2011. ${ }^{16}$

In early 2013, three top-tier jihadist forums were active under the umbrella of al-Fajr Media: the Ansar al-Mujahidin Network (shabakat ansar al-mujahidin, "supporters of mujahidin network"), the Shumukh al-Islam Network (shabakat shumukh al-Islam, "loftiness of Islam network"), and the al-Fida' Islamic Network (shabakat al-fida' alIslamiyya, "sacrifice Islamic network"). 


\section{Social Media and Jihadist Online Communication}

When social media platforms first emerged, jihadist groups preferred to use them by posting links that pointed back to the secure space of official websites or jihadist forums, which continued to serve as tools for authentication..$^{17}$ This certainly had to do with the existing hierarchical system of verification embodied by al-Fajr Media that was feeding the forums. ${ }^{18}$ By contrast, social media increased the possibilities for their opponents, be it state agencies, online activists or ordinary people, to counter jihadist propaganda by posting alternative views, spreading disinformation or using blatant impersonation.

This notwithstanding, jihadist forums, whose self-imposed role was to mediate between terrorist groups and larger audiences, felt that they needed to reach out to social media. Since 2011, Ansar al-Mujahidin and Shumukh al-Islam, among others, actively encouraged supporters to develop social media profiles. ${ }^{19}$ The Ansar alMujahidin English Forum created a Twitter account in October 2011, whereas the Arabic forum of Ansar al-Mujahidin created a Facebook page, also in 2011, which was fed automatically with contents from the forum. ${ }^{20}$ These efforts served to reach out to social media users and lure them to their platforms.

Individual jihadist supporters also used social media to promote jihadist perceptions. They took advantage of the activities of nonviolent activists in Syria that in 2012 were documenting human rights abuses and war crimes by the Syrian regime of Bashar al-Asad:

Social-media smart and professional jihadists adopted this treasure grove for their propaganda. By rebranding and reframing the content created by civil society activists, jihadi propaganda used these grievances to support a key jihadist self-perception; the obligation to respond by force to defend and protect the Sunnites in Syria. ${ }^{21}$

Following them, self-styled media outlets started creating social media accounts, in particular on Twitter, from where they linked to content available on jihadist forums, but also other social media platforms, primarily YouTube and Facebook. As a result, networks on Twitter sharing jihadist content began coexisting with jihadist forums. ${ }^{22}$

By 2013, a prominent jihadist online author, Abu Sa'd al-Amili, lamented a general decline in participation on jihadist forums. One of the reasons for this, in his view, was that jihadists were migrating to social media platforms such as Twitter and Facebook. Whereas the displacement was caused in part by the frequent disruption of the forums, he added, in the long run relying on social media was an error that endangered the central position of jihadist forums, "our protected strongholds." People needed to recognize that social media were no adequate alternative to the forums, for they were run by "our enemies." Inevitably there would come a day when "they shut their doors in our faces." Therefore, the forums should remain the "base and foundation" of jihadists online. ${ }^{23}$

\section{Centralized Social Media Profiles}

During the same period, Jabhat al-Nusra and ISIL recognized that they could not afford abandoning social media to their opponents or supporters, for fear that these activities, 
if left uncontrolled, could dilute the corporate identity of the group. In early 2013, Jabhat al-Nusra's official Twitter account was embedded in a large network of supporting accounts. ${ }^{24}$ In the course of the year, Jabhat al-Nusra published a series of "media statements," 25 signed by its central media outlet al-Manara al-Bayda' Media Company (mu'assasat al-manara al-bayda' al-i'lamiyya, "white minaret [of the Umayyad mosque in Damascus] media company"), in which it tried to regulate the activities of its supporters on Twitter. In order to avoid confusion between official accounts and supporters' accounts, the group asked supporters that created accounts using the name or logo of Jabhat al-Nusra or al-Manara al-Bayda' Media to change this and to state "in a stable, visible place" on their pages that these were supporting, not official, pages. ${ }^{26}$ The group insisted that it had no official website, forum, Facebook account, or Wordpress page, after the initial ones had been suspended. The only official accounts of Jabhat al-Nusra were those on the three major jihadist forums at the time, the Shumukh al-Islam Network, the Ansar al-Mujahidin Network, and the al-Fida' Islamic Network, supported by Jabhat al-Nusra's Twitter account (@JbhtAnNusrah, then after suspension of the former @JabhtAnNusrah), "as a secondary source for Jabhat [alNusra]'s publications." ${ }^{27}$ Initially, the split between Jabhat al-Nusra and ISIL, which occurred in April 2013, did not affect these positions.

In addition, on 7 July 2013, a new media outlet on Twitter was introduced: the Himam News Agency (@Hemm_Agency, wikalat himam al-ikhbariyya, “concerns news agency"). Himam News was described as an independent media company based in Syria, which aimed to report on "the life of the mujahidin in particular, living their victories, telling their heroic deeds and following their social life." It was "concerned with covering the living conditions of Muslims in general, report their opinions, picture their creativity and tell their stories." 28 The idea of creating a purportedly independent news agency reporting on the non-combatant activities of a specific jihadist group had a precedent in the Madad News Agency, which was created by Ansar al-Shari'a in Yemen in 2011-12, when it was able to cease control of territory in southern Yemen. ${ }^{29}$

Himam News immediately started posting short videos, uploaded to YouTube and advertised on its Twitter account, showing the provision of aid and services by Jabhat al-Nusra to the local population and interviews with local residents on the benefits of Jabhat al-Nusra's administration. In a tweet on its official Twitter account in January 2014, Jabhat al-Nusra declared that Himam News's correspondents were "deployed to most regions in Syria, covering the activities of Jabhat al-Nusra in the liberated areas."30 Himam News was active until late August 2014, after which it disappeared. ${ }^{31}$

In the same period, following the April 2013 split, ISIL started creating its own media profile. In mid-August 2013, ISIL declared that, during a temporary interruption of the publication of its statements and media productions, which was due to "the known circumstances through which the Levant arena has gone," supporters on social media accounts had tried to fill the gap by posting news and comments with regard to ISIL. ${ }^{32}$ Others, however, exploited the opportunity to spread, under its name, "fabricated news, exaggerations and opinions that do not express the programme and direction" of ISIL. Some of these used names, titles, and logos of ISIL or one of its media outlets, such as al-Furqan Media or al-I'tisam Media, to suggest an official link or by claiming that they were linked to some field commander in Syria. The statement insisted that the only 
official communication channels of the group were the al-I'tisam Media account on the Shumukh al-Islam Network and its official Twitter account.

The al-I'tisam Media Production Company (mu'assasat al-i'tisam lil-intaj al-i'lami, "adherence [to God's rope] media production company") had emerged in March 2013 with a first video production that still focused on terrorist activities in Iraq. ${ }^{33}$ It was described as an entity of the "information ministry" (wizarat al-i'lam) of ISI. Since August 2013, al-I'tisam Media started issuing a series of videos, the "Windows onto the land of epic battles" (nawafidh ala ard al-malahim) series, which combined coverage of ISIL combats with social activities and services provided to the population in areas controlled by ISIL. ${ }^{34}$ These videos were posted simultaneously on jihadist forums and the official Twitter account of al-I'tisam Media, which was suspended and had to be re-created several times in 2013. Whereas al-I'tisam Media functioned in ways similar to those of Himam News, it had been identified since the beginning as an official media outlet of ISI/ISIL. Maybe for this reason the brand of al-I'tisam Media was abandoned in 2015. By this time, its news agency function had been replaced by A'maq News, which, starting in late 2014, has functioned as an allegedly independent "news agency" covering IS activities.

Thus, the split in 2013 was followed by a period in which both groups tried to develop centralized media profiles that were adapted to social media use. Nevertheless, the forums still served as a backup and authentication tool in case of account suspension and impersonation attempts on Twitter. Followers of both groups were requested to identify their services clearly as supporting activities.

\section{Diffusion}

This situation changed in 2014. The tensions between ISIL and the rest of the Syrian armed opposition escalated into large-scale violence through an attempt by large segments of the opposition to drive ISIL out of Syria at the turn of 2014. Jabhat al-Nusra first tried to mediate, but was quickly drawn into the conflict. As a result of the intransigent positions of ISIL, Al Qaeda's central leadership officially excluded the group from the Al Qaeda network in late January $2014 .{ }^{35}$ ISIL's defiant attitude seemed to be justified in the light of its military successes: in June ISIL forces conducted a large-scale offensive from Syria across the Iraqi border, taking control of large swathes of northern Iraq, including the second largest Iraqi city Mosul. Shortly afterward, ISIL announced that it had reestablished the caliphate, changed its name to Islamic State and declared that all other jihadist groups in areas being or coming under its control were thereby dissolved. It thus may not come as a surprise that, in late July, Jabhat al-Nusra vowed to deliver, in cooperation with other jihadist groups in Syria, the land and the people from extremists, in a clear reference to IS. ${ }^{36}$

In January 2014, ISIL started creating specific Twitter accounts for each of its "provinces" (wilayat, sing. wilaya), which reported on local events. Maybe this was triggered by a disruption of communications between regional ISIL factions and the centralized media outlets due to the hostilities. The "provincial" Twitter accounts quickly developed into a network with a corporate identity, in which, if one account was suspended, the others could be used to authenticate an account newly created to replace 
the suspended one. Included in this network of accounts were also those of the official media outlets, including al-Furqan Media and al-I'tisam Media. This resulted in a network with sufficient resilience to withstand occasional suspensions. As a result, ISIL/IS was not forced anymore to rely on the authentication through the forums.

Whereas in April 2014, Jabhat al-Nusra still denied that al-Manara al-Bayda' Media had an official Twitter account, ${ }^{37}$ it changed its position shortly afterward, probably in reaction to the new strategy developed by IS. In July it introduced a Twitter account for the "network of correspondents of al-Manara al-Bayda'," whose aim was "continuous coverage of local Jabhat al-Nusra news from different regions." ${ }^{38}$ Al-Manara al-Bayda' Media's "network of correspondents" functioned in ways similar to the ISIL network of "provinces," with Twitter accounts with regional responsibilities that served to authenticate one another in case of suspension.

The resilience of IS's network of accounts was put to the test by the start of proactive suspension of accounts promoting terrorism by Twitter. The platform started developing capacities to disrupt IS propaganda messaging on a massive scale in August 2014, after IS had published a video showing the assassination of U.S. American journalist and video reporter James Foley. ${ }^{39}$ IS tried to recreate its network of accounts on other platforms, including VKontakte (vk.com), but was quickly evicted. The group had to change strategy again and decided to replace authentication through dedicated accounts by authentication through the creation of massive numbers of accounts that posted identical messages simultaneously. These accounts were bound together by hashtags, first referring to IS "provinces" or its central media outlets, then to titles of new releases. These hashtags ensured that, even if accounts were deleted quickly, it was possible to find other postings that were still active. This system remained workable until the 13 November 2015 attacks in Paris, after which the hashtags were massively spammed by IS opponents. ${ }^{40}$

During the same period, Jabhat al-Nusra's "network of correspondents" faced suspensions to a far lesser extent and could largely maintain its network of "correspondents" even after it renamed into Jabhat Fath al-Sham in July 2016, relinquishing publicly its relation to Al Qaeda. While the brand of al-Manara al-Bayda' Media was abandoned after the change, the "network of correspondents" remained active, until Jabhat Fath alSham merged with other jihadist groups to form Hay'at Tahrir al-Sham in early 2017. Changing corporate identity might have been another strategy to evade eviction.

\section{The Reaction of the Forums}

By the end of 2014, then, both IS and Jabhat al-Nusra had implemented strategies to maintain a sufficiently resilient presence on Twitter and distinguish their message from disinformation without the need for authentication through jihadist forums. A major motivation for this was certainly the need to be present in the space where their supporters communicated. In addition, it now became clear that the forums were not the independent entities that they purported to be, and the fact that they had to show loyalty to either camp weakened their position further. In what follows, the positions of two of the major forums, the Ansar al-Mujahidin Network and the Shumukh al-Islam 
Network, are examined. Ansar al-Mujahidin remained firmly within the al-Fajr Media network, whereas Shumukh al-Islam sided with IS.

With regard to the mounting tensions in Syria, the administrators of Ansar alMujahidin warned, in September 2013, all "those who follow [Ansar al-Mujahidin] and all other writers and Muslims on Twitter that have commented on recent events" that they had to be careful not to side with one of the conflicting parties and to abstain from slandering the opposing party. ${ }^{41}$ Supporters were asked to convey a positive image of the "mujahidin" and their supporters and avoid inciting Muslims, and in particular Muslim scholars, against them. They were enjoined to think highly of Muslims in general, and jihadist scholars in particular. In light of this advice, Ansar al-Mujahidin stated its commitment to remain neutral in the conflict between different jihadist groups or currents and to prevent its members from verbally attacking or insulting Muslims and jihadist scholars, while allowing constructive criticism. At the same time, Ansar alMujahidin emphasized that its abstention from publishing official releases of a particular group was not to be understood as an attack or an insult and did not put into question the validity of the struggle of this group. Finally, it stressed that the official position of the Network was published exclusively on its official accounts on "jihadist networks," that is forums, and on its official Twitter account.

The statement seems to be directed primarily to supporters of ISIL at the time, due to its emphasis on the respect due to jihadist scholars. Most prominent jihadist ideologues had supported Al Qaeda in the dispute and now faced strong reactions from social media users sympathetic of ISIL. The forum administrators admitted indirectly that they stopped publishing ISIL releases but tried to explain that this was not to be seen as criticism. One cannot escape the impression that this decision might have been imposed on the forum by the al-Fajr Media administration. At some point after this, the Arabic Ansar al-Mujahidin forum disappeared from the Internet. ${ }^{42}$

Shumukh al-Islam's story is very different. In a first reaction after the outbreak of violence between the ISIL and other armed opposition groups in Syria, the Shumukh alIslam Network issued, on 5 January 2014, a statement in support of ISIL. ${ }^{43}$ In its capacity as

one of the frontlines [thaghr] of jihadi media, which provided its best men for the cause of continuing the word of truth, unifying the ranks of the mujahidin, containing the dissentions and calamities brought to us by the Crusader enemy and his supporters from among those who wear the garment of advice and concern for the religion,

the Shumukh al-Islam Network deplored the state of "our brothers in the Levant of caliphate, especially our brothers in the Islamic State in Iraq and the Levant [ISIL]," who for many years had been steadfast and perseverant, but now faced new ways employed by the enemies of Islam, who

have found a new location in which to squirt out their venom and evil-Twitter-after the jihadi networks had restrained them, repelled their obstruction and counteracted them with all might. Some of them wear the garment of religion to lead [others] astray from God's path and issue fatwas on the killing of mujahidin and the lawfulness of [shedding] their blood.

The statement continued by pointing out that a war was being waged against the "mujahidin for God's cause" in Syria by "criminal gangs" equipped and trained by 
Istanbul and Amman, after some armed factions were incited to fight against "our brothers in the Islamic State." They killed both "ansar" (i.e., Syrian members) and "muhajirun" (i.e., foreigners) and attacked the families of the "muhajirun." In the light of this, the Shumukh al-Islam Network demanded that all truthful "mujahid" groups side with the ISIL in this proxy war, for this was not a war against Abubakr alBaghdadi and his men but against anyone who strove to implement the Sharia. Any incitement against ISIL had to stop, and a Sharia tribunal was to be established to identify those responsible for the in-fighting. The authors stressed that self-defense and the repelling of aggression were legitimate under Islam.

Shumukh al-Islam's appeals for protecting ISIL against the aggression that it suffered continued until the administrators officially declared their support of ISIL in a statement published on 10 March 2014. ${ }^{44}$ The authors insisted that the Shumukh al-Islam Network had existed for seven years,

during which we have lost many of our cadres, while the others are awaiting [capture], are captives or exiles, all for the sole purpose of communicating the voice of the people of jihad to the umma;

seven years of supporting the mujahidin and striving for unity of their ranks without creating fissions between them;

seven years of advising and directing the supporters of jihad;

seven years of clarity of vision and programme.

In the current circumstances, the statement continued, Shumukh al-Islam needed to take a position and, therefore, declared that it supported ISIL, against which all nations of unbelief, hypocrisy, and apostasy had conspired. Nevertheless, Shumukh al-Islam would not tolerate on its platform anyone slandering or defaming jihadist scholars or commanders, including Ayman al-Zawahiri. Such members would be expelled: "We cannot let Shumukh [al-Islam] become pasture for those who want to behave in evil manners and attack jihadi commanders and their representatives." In line with this, Shumukh al-Islam would provide advice and direction to Jabhat al-Nusra, which at the same time it accused of helping "apostates, rebels, thieves etc., who fight our brothers in the [Islamic] State." Shumukh al-Islam considered Jabhat al-Nusra "our brothers," whom they were obliged to guide back to the truth. All postings inciting further conflict would be prevented. Nevertheless, all members of Shumukh al-Islam, in particular its senior members, were called upon to strive for reconciliation between the "mujahidin" and to close the ranks. The statement finished with a renewed call for a Sharia tribunal to settle the conflict between Jabhat al-Nusra and ISIL.

In response to this statement, Jabhat al-Nusra announced that it would stop distributing its propaganda via the Shumukh al-Islam Network. "Since the start of the dispute between Jabhat [al-Nusra] and the [Islamic] State and the interruption of the publication [of propaganda statements], while we all awaited the decision of Shaykh [Ayman] al-Zawahiri," 46 and even after its publication, Shumukh al-Islam sided with the ISIL. Shumukh al-Islam was accused of not taking action against forum members openly insulting Jabhat al-Nusra. Recent publications by its "media arm," in a likely reference to Shumukh al-Islam's al-Ma'sada Media Company, showed that it had lost "every meaning of professionalism and trustworthiness, on which the lofty edifice of media jihad had been based for years." 
In late April 2014, Shumukh al-Islam appealed to its supporters-“you should consider yourselves family of the al-Shumukh house"- to show commitment by contributing to remedy and contain the conflict. ${ }^{47}$ Public forums and chatrooms should not be used to discuss the origin of the conflict. This should be left to jihadist leaders and advisers (ahl al-hall wal-aqd) ${ }^{48}$ in private conversations. Equally, the conflict should not be transferred to arenas outside Syria. Shumukh al-Islam was committed to containing it and so should its members. Shumukh al-Islam pledged that, in addition to ISIL productions, it would continue publishing propaganda items from all groups accredited with al-Fajr Media (jami' al-jihat al-mu'tamada lada al-Fajr), as long as those materials did not openly oppose one of the parties in the conflict. It declared that it had launched a "media initiative" to bring the concerned parties- "the [Islamic] State, Jabhat [alNusra], al-Fajr [Media], al-Fida' [Network]”-back together. Shumukh al-Islam emphasized again that constructive criticism was wanted but verbal attacks and slander would not be tolerated. Any content that might increase hatred and tension would be deleted. Unacceptable behavior on Shumukh al-Islam included the use of links to the Network in content that was copied and pasted from it, presumably to social media, without prior permission. Official publications of jihadist groups were to be disseminated exclusively through official accounts, with the exception of those that were disseminated through official Twitter accounts. It was forbidden to copy insults and false information from Twitter and other social media into Shumukh al-Islam. Shumukh al-Islam should be a place of support only. Silence should be kept about the "mujahidin's" disagreements or situation, the reality of which was unknown to outsiders (and, thus, to the community of online supporters of either camp).

What is striking in Shumukh al-Islam's attitude is its insistence on the length of its struggle and the sacrifice that it had made. This seems to suggest that its long-standing legitimacy as one of the major jihadist forums was at stake when it started supporting ISIL, likely in defiance of instructions given by al-Fajr Media. The reference to Twitter as a main arena in which the fight against ISIL was led reveals that the competition with social media was perceived as another threat to the position of the forum as central communication space.

Whereas Shumukh al-Islam supported ISIL, it tried to keep its position as an independent service provider to all jihadist groups, which is evidenced by its pledge not to allow the slandering of Ayman al-Zawahiri and to publish material from all groups linked to al-Fajr Media, as long as they did not contain inflammatory statements against one of the parties. Nevertheless, Shumukh al-Islam's condescending attitude toward Jabhat al-Nusra led the latter to disown it. The appeals for a tribunal to settle the conflict illustrate the forum's difficult position, in the light of ISIL's categorical refusal to submit to mediation. In the end, Shumukh al-Islam tried to contain the conflict by preventing users from discussing its causes on the forum and from applying it to areas outside Syria. To achieve this, it intended to control the contents that were copied from and to social media.

Another aspect is of importance: Shumukh al-Islam actively tried to involve its supporters to contribute to the struggle and get involved. Likely in response to its weakened relations with al-Fajr Media, Shumukh al-Islam seems to have sought to compensate the impending loss of relevance by attracting new actors that had appeared on social media. 


\section{Re-Configuration}

In the meantime, supporters of the two camps were already re-grouping on social media. A comprehensive overview of these initiatives cannot be provided here due to limited space. Two examples will be discussed, one in support of $\mathrm{Al}$ Qaeda and one in support of IS.

In April 2014, the al-Tahaya Media Company (mu'assasat al-tahaya lil-i'lam, "rememberances media company") was established. In its founding statement, ${ }^{49}$ the entity stated that "after the jihadi media reached a dangerous and rough stage that needs [taking] a stance of review, reconstruction and re-assessment after a state of chaos, and imposing a realistic policy by some [media] companies on the mujahidin and their supporters," the al-Tahaya Media Company was launched as "one spearhead of the mujahidin against the imams of unbelief and hypocrisy," which would "represent our commanders, scholars, mujahidin and prisoners." In particular, al-Tahaya Media defined as its tasks "the transcription and translation of material issued by the [two official Jabhat al-Nusra media outlets], the al-Basira and al-Manara al-Bayda' Companies" and "some works of truthful mujahidin everywhere." It specifically committed to "the policies of our brothers in the al-Fajr Media Centre."

Since its launch, al-Tahaya Media has issued hundreds of documents, including transcripts of video and audio speeches by $\mathrm{Al}$ Qaeda leaders and ideologues. ${ }^{50}$ Its main aim seems to be to put these texts into circulation on social media and file sharing sites and, thereby, ensure that they remain available also outside jihadist forums and websites. ${ }^{51}$ Its explicit reference to the al-Fajr Media Centre shows that this endeavor aimed to perpetuate the centralized hierarchical communication structure built by Al Qaeda.

By contrast, the creation of the Media Front for the Support of the Islamic State (al-jabha al-i'lamiyya li-nusrat al-dawla al-Islamiyya) was the culmination of a selforganization of activists, bringing together a number of self-proclaimed entities on social media that were supporting IS. In its founding manifesto, published in October $2014,{ }^{52}$ the authors announced that the "media soldiers in support of the State of Islam" created a "unified central leadership" comprising the "most important supporting jihadi media companies" to "support the blessed global caliphate project." As examples of the effectiveness of online propaganda, they referred to the "terror" sparked in America by the decapitation of James Foley, the effect of Twitter hashtag campaigns and the productions of IS's al-Hayat Media Centre, which specialized in propaganda, such as the English-language magazine Dabiq, directed to non-Arab audiences. The "legend of the lone wolf," the statement said, was over. IS supporters should join the "structure of your blessed front" (i.e., the Media Front). In particular, they appealed to technical experts, hackers, translators, media activists, graphic designers, video and audio producers, experts in Arabic language, scenario writers, nashid composers, and poets to join. People that did not have such capabilities could transcribe texts, upload files, and disseminate them on social media. All participating entities would conserve their original name. The statement contains a list of entities that joined the Media Front: al-Ghuraba' Media; al-Wafa' Media Production; al-Battar Media; al-Wagha Media; al-Ansar League; A'isha Media Centre; Minbar al-Ansar Room; Fada'ih al-Almaniyya Media Production; Dabiq Media; Mahsud Jihadi Media; al-Minhaj Media Production; 
Nasa'im Audio Production; Adwa' al-Ribat Media Production; al-Raqqa Islamic Network; and al-Ansar Islamic Network.

Some of the entities composing the Media Front for the Support of the Islamic State subsequently became prominent media outlets on social media promoting IS. They developed close relationships with the organization. ${ }^{53}$

\section{Analysis}

The competition between Jabhat al-Nusra and ISIL after April 2013 accelerated a process that had been underway for some time, the migration of jihadist activity from discussion forums to social media. As a result, it helped to speed up the loss of relevance of jihadist forums, which had been undermined over the years by infiltration and disruption.

Individual supporters of jihadism had started using Twitter and other social media platforms long before, and their activity had reached an extent that put the jihadist groups at risk of losing control over their communication. The groups thus had to relinquish their initial reluctance and establish their own presence on social media, in particular Twitter. The matter acquired more urgency after the April 2013 split between Jabhat al-Nusra and ISIL, when neither could afford leaving the field to its competitor.

Already at this stage, the two groups chose slightly different approaches. Jabhat alNusra remained firmly within the al-Fajr Media system with its three major forums, using Twitter only as a "secondary" source for its official releases. It, nevertheless, supplemented its official media outlet, al-Manara al-Bayda' Media, with a new format adapted to social media, Himam News. By contrast, from the beginning, ISIL treated Twitter and the Shumukh al-Islam Network, the only top-tier forum openly siding with it, as equally valid sources for its propaganda. This might have been due to an initially weak position, as the growing conflict with Al Qaeda risked leading to the exclusion of ISIL, and consequently Shumukh al-Islam, from established distribution channels. ISIL, to a certain extent, copied Jabhat al-Nusra's approach of establishing a media outlet adapted to social media, al-I'tisam Media, even if the distribution of tasks between the former and ISIL's central media outlet, al-Furqan Media remained less clear. In this initial phase both groups adopted a strategy of strict branding to authenticate their messages on Twitter.

The reliance on branding of official accounts with possible verification through the forums served the requirement of authentication. It, however, offered only limited resilience and carried the risk of interruption of messaging during the time needed to announce a new account through the forums, thereby opening opportunities for the opponent. This likely motivated the development of a new strategy relying on a network of accounts that were used to introduce and verify new accounts without passing through the forums. ISIL "provincial" accounts, possibly created following a temporary breakdown of the centralized communication system of ISIL in early 2014, rapidly developed into a network with a clear corporate identity on Twitter, thereby forming an additional layer in which the official media outlet accounts were embedded. The fact that Jabhat al-Nusra adopted a similar system on Twitter indicates that it was deemed a successful strategy. In addition to providing additional breadth to the reporting, the 
new system afforded relative resilience against suspensions and independence from jihadist forums for verification and the related delay or interruption of messaging. Thus, for the first time, Jabhat al-Nusra and ISIL bypassed the forums, a fact that contributed greatly to the latter's loss of relevance.

Another factor is the apparent breakdown of the centralized distribution system controlled by Al Qaeda through the al-Fajr Media Centre. The reactions of the forums put in evidence the former central position of al-Fajr Media. On the one hand, the example of Ansar al-Mujahidin shows the continuing commitment to the al-Fajr Media network. Shumukh al-Islam's example, on the other hand, with the forum insisting on its long trajectory of jihadist activism, clearly displays fear of losing legitimacy in case of exclusion, presumably as a result of disobedience. To compensate, Shumukh al-Islam tried to mobilize its followers to work toward reconciliation. In addition, and contrary to ISIL, Shumukh al-Islam warned its supporters of the dangers of Twitter and, finally, tried to impose strict controls on the information exchanged between the forum and Twitter. All these attempts seem to have remained largely futile.

During the same period, efforts increased to structure supporters' activities on Twitter in support of the two camps. While the available sources do not allow establishing a personal link between the entities, by referring to al-Fajr Media in its founding statement, al-Tahaya Media put itself in the line of tradition of Al Qaeda's supervisory body and tried to preserve Al Qaeda's legacy on the Internet. By contrast, ISIL supporters created self-styled media entities on Twitter, which then formed an alliance of media activists that actively recruited skilled, like-minded individuals. It is more than likely that these networks of supporters on social media served as a recruitment pool for IS's media capabilities. This explains the enormous innovation capacity of IS with regard to media production and dissemination that gained it its ascendancy in the online sphere for the major part of 2015 and 2016.

When IS supporters were finally forced to seek alternative platforms to replace the increasingly contested space on Twitter, they did not fall back on jihadist forums. At the time of writing, Shumukh al-Islam continued active-despite frequent changes of its Uniform Resource Locator, probably as a result of disruption efforts-and posted IS propaganda in a timely manner. However, only registered users could access content posted on it; and no possibility to register new accounts was provided. ${ }^{54}$ In addition, technology has evolved, and discussion forums that are difficult to access from smartphones and other mobile devices are far less attractive at present. Instead, the bulk of jihadist supporters and consequently also terrorist groups and their media outlets have moved to Telegram, a cloud-based encrypted messaging service that allows recreating the community that cannot thrive anymore on Twitter. ${ }^{55}$ Jabhat al-Nusra was exposed to a lesser degree to suspensions ${ }^{56}$ and, thus, was not forced to innovate.

\section{Conclusion}

For terrorist groups, public communication fulfills multiple purposes, including intimidating opponents, justifying violent acts, and attracting volunteers and funding. To achieve this, they need access to public space and, simultaneously, must ensure that 
their audiences can distinguish their messages from the surrounding noise and disinformation. The period under review illustrates the interplay between these two basic, but often contradicting, requirements of terrorist communication in a hostile online environment.

Terrorist groups must be present in places where their supporters are, if they want to exercise some degree of control over what is said about them, both by their supporters and opponents. Forums and Twitter both provide a public space to the extent that information posted on both types of platforms can be accessed openly and is indexed by search engines. Twitter, of course, offers far greater opportunities to engage directly with audiences beyond the closed jihadist community.

On forums, authentication is achieved through distribution channels providing exclusive access to original material from terrorist groups, on the one hand, and the control of the content through forum administrators, on the other. It has become apparent that the impression of independence of the forums needs qualification, as at least the major ones have been engaged in a hierarchical relationship with terrorist organizations, as exemplified by Al Qaeda's al-Fajr Media. Their legitimacy resided in the faithful implementation of the publishing policies defined by al-Fajr Media.

Such internal disciplinary mechanisms are absent on Twitter. Unable to control content directly, terrorist groups needed to be present on Twitter themselves, to counter their opponents as much as to discipline their supporters. They thus started to disseminate their content directly without the services of forum administrators. New authentication mechanisms needed to be designed, such as the use of networks of accounts to create resilience. Simultaneously, the competition between IS and Al Qaeda led to the creation of new media outlets and an escalation of content production.

Social media platforms not only challenged the established communication methods of terrorist groups but made it difficult for jihadist activists to influence the discourse in ways done by forum administrators in the past. The equivalent of forum administrators on Twitter, and now Telegram, is media entities established with the purpose to support a terrorist group. Contrary to forum administrators, these entities cannot exercise control over the content posted by other users and must try to influence their audiences with their own content output, which must be disseminated widely and clearly branded to achieve authentication.

Some entities, such as al-Tahaya Media, which presumably have direct access to a network controlled by a terrorist group, apply a top-down approach, aiming to maintain available online central texts and utterances of the group that they support. Others, as those organized in the Media Front for the Support of the Islamic State, grow bottomup, creating alliances of seemingly independent entities to form a front in support of a certain group, presumably one that breaks with established communication patterns.

Whatever strategies are devised to maintain a presence in a hostile online environment, these do not result from a carefully designed plan but respond in flexible ways to current challenges. The answers found are subsequently formalized into a strategy that serves until the next wave of disruption necessitates further innovation.

The shift of Jabhat al-Nusra and IS from forums to Twitter goes to show that innovation in communication is a reaction to external pressure. The al-Fajr Media Centre was established to stabilize the system of discussion forums that had formed as a 
reaction to attacks on websites. Once established, however, for a long time, the al-Fajr Media system hindered innovation with regard to exploiting the new opportunities of the social media by Al Qaeda-linked groups. Eventually, it was the escalating conflict within the jihadist movement and, consequently, the breakdown of the al-Fajr Media system that spurred innovation and pushed the groups into the hostile environment of Twitter. Here, innovation was led by IS, which through its depiction of extreme violence and aggressive incitement of terrorism, quickly managed to concentrate countermeasures on itself.

Cut off from the established information distribution channels and facing increasing disruption efforts, IS reached out for new talent and within a short period of time used this innovative force to create the most powerful propaganda machinery known from any nonstate group in history.

\section{Acknowledgments}

I thank Noha Eid, Antonios Samouris, Manuel Torres Soriano, and the two anonymous reviewers for their useful comments on a draft of this article. All remaining errors of fact or judgment are mine.

\section{Notes}

1. Aaron Y. Zelin, "The State of Global Jihad Online: A Qualitative, Quantitative, and CrossLingual Analysis," New America Foundation, January 2013; Manuel Ricardo Torres-Soriano, "The Dynamics of the Creation, Evolution, and Disappearance of Terrorist Internet Forums," International Journal of Conflict and Violence 7, no. 1 (2013), 164-178.

2. Thomas Hegghammer, "Can You Trust Anyone on Jihadi Internet Forums?," in Fight, Flight, Mimic: Identity Signalling in Armed Conflicts, ed. Diego Gambetta (Oxford: Oxford University Press, forthcoming), draft available at http://hegghammer.com/_files/ Interpersonal_trust.pdf.

3. Today, jihadist terrorist groups such as the so-called Islamic State (IS) and, maybe to a lesser extent, Al Qaeda do not have a sustained presence on Twitter. Accounts that are clearly marked as representing or supporting these organizations are quickly deleted. Maura Conway et al., Disrupting Daesh: Measuring Takedown of Online Terrorist Material and Its Impacts (No place: Vox-POL, 2017), http://www.voxpol.eu/download/vox-pol_publication/ DCUJ5528-Disrupting-DAESH-1706-WEB-v2.pdf (accessed on 19 September 2018).

4. Zelin, "The State of Global Jihad Online," 10.

5. Torres-Soriano, "The Dynamics," 175.

6. For example, the al-Shabab al-Mujahidin Movement in Somalia created its first Twitter account in December 2011. Alexander Meleagrou-Hitchens, Shiraz Maher, and James Sheehan, "Lights, Camera, Jihad: Al-Shabaab's Western Media Strategy," The International Centre for the Study of Radicalisation and Political Violence (ISCR), 2012, 31, http://icsr. info/wp-content/uploads/2012/11/ICSR-Lights-Camera-Jihad-Report_Nov2012_ForWeb-2.pdf (accessed on 19 September 2018).

7. AQIM created its first Twitter account in March 2013. Manuel R. Torres-Soriano, "The Caliphate is Not a Tweet Away: The Social Media Experience of Al Qaeda in the Islamic Maghreb," Studies in Conflict \& Terrorism 39, no. 11 (2016), 968-981.

8. Gunnar J. Weimann, "Between the Arab Revolutions and the Islamic State's Caliphate: AlQaeda Leaders' Online Propaganda 2012-2014," in Terrorists' Use of the Internet: 
Assessment and Response, ed. Maura Conway, Lee Jarvis, Orla Lehane, Stuart Macdonald, and Lella Nouri (Amsterdam: iOS Press, 2017), 129-145.

9. Akil N. Awan and Mina al-Lami, "Al-Qa'ida's Virtual Crisis," The RUSI Journal 154, no. 1 (February 2009), 56-64, at 56.

10. "Internet is a battlefield for jihad, a place for missionary work, a field of confronting the enemies of God. It is upon any individual to consider himself as a media mujahid, dedicating himself, his wealth and his time for God." Al-Fajr Media Centre statement, 6 May 2011, quoted in Nico Prucha, "Online Territories of Terror-Utilizing the Internet for Jihadist Endeavors," Orient 52, no. 4 (2011), 43-47, at 46.

11. A precursor of this attitude is found in early jihadist magazines, such as the al-Ansar newsletter or Al Qaeda in the Arabian Peninsula (AQAP)'s Sawt al-Jihad, which contained sections reporting on jihadist activities in different conflict zones. Undoubtedly, jihadist online propaganda has been instrumental for fostering the global character of the jihadist movement.

12. This assessment is based on statements in private communications by administrators of the Ansar al-Mujahidin Network. Manuel R. Torres-Soriano, "The Hidden Face of Jihadist Internet Forum Management: The Case of Ansar Al Mujahideen," Terrorism and Political Violence 28 (2016), 735-749, at 741.

13. Brynjar Lia, "Jihadi Web Media Production: Characteristics, Trends, and Future Implications," Norwegian Defence Research Establishment (FFI), 2007, 12.

14. Torres-Soriano, "The Hidden Face," 743.

15. Ibid. See for example a December 2012 statement by the al-Fida' Islamic Network, announcing its return online and thanking the "technical committee" of al-Fajr Media for their support. "New Statement from al-Fidā' Arabic Forum: 'On the Occasion of the Return of al-Fidā', the Opening of Registration for One Day," Jihadology, 17 December 2012, http://jihadology.net/2012/12/17/new-statement-from-al-fida-arabic-forum-on-the-occasion-ofthe-return-of-al-fida-the-opening-of-registration-for-one-day (accessed on 19 September 2018).

16. Torres-Soriano, "The Hidden Face," 740.

17. See, for example, Shaun Waterman, "Terrorists Discover uses for Twitter: Other Social Media Blocked or Limited," The Washington Times, 28 April 2011, http://www. washingtontimes.com/news/2011/apr/28/terrorists-discover-uses-for-twitter (accessed on 19 September 2018).

18. In a comment on ibid., Will McCants suggested that what held jihadist groups from using Twitter was the vulnerability of Twitter accounts, which could be easily suspended, and the highly effective system of jihadist forums that had evolved since 2005. Will McCants, "Why Don't Jihadi Orgs Tweet?" Jihadica, 30 April 2011, http://www.jihadica.com/why-dontjihadi-orgs-tweet (accessed on 19 September 2018).

19. Nico Prucha, "IS and the Jihadist Information Highway-Projecting Influence and Religious Identity via Telegram," Perspectives on Terrorism 10, no. 6 (December 2016), 48-58, at 50.

20. Gabriel Weimann, "Terror and the Internet," International Encyclopedia of the Socal \& Behavioral Sciences, 2nd edition, Volume 24, 227-236, at 231-232.

21. Nico Prucha, "Jihadi Twitter Activism-Introduction," Jihadica, 27 April 2013, http://www. jihadica.com/jihadi-twitter-activism-introduction (accessed on 19 September 2018).

22. Ibid.

23. Cole Bunzel, "Are the Jihadi Forums Flagging? An Ideologue's Lament," Jihadica, 20 March 2013, http://www.jihadica.com/are-the-jihadi-forums-flagging-an-ideologue $\% \mathrm{E} 2 \% 80 \%$ 99s-lament (accessed on 19 September 2018).

24. Nico Prucha and Ali Fisher, "Tweeting for the Caliphate: Twitter as the New Frontier for Jihadist Propaganda," CTC Sentinel 6, no. 6 (June 2013): 19-23; Ali Fisher, "Swarmcast: How Jihadist Networks Maintain a Persistent Online Presence," Perspectives on Terrorism 9, no. 3 (June 2015): 3-20.

25. Jabhat al-Nusra, Bayan i'lami raqm (5): shukr wa-i'tidhar [Media statement no. 5: thanks and apologies], al-Manara al-Bayda' Media Company, posted on 13 February 2013, https:// justpaste.it/1ywj (accessed on 19 September 2018); Jabhat al-Nusra, Bayan i’lami raqm (6): 
itlaq hisab Jabhat al-Nusra al-rasmi ala Twitter [Media statement no. 6: launch of Jabhat alNusra's official account on Twitter], al-Manara al-Bayda' Media Company, posted on 24 August 2013, https://justpaste.it/4iij (accessed on 19 September 2018); Jabhat al-Nusra, Bayan i’lami raqm (7): tajdid hisab Jabhat al-Nusra al-rasmi ala Twitter wa-kalima lilmunasirin [Media statement no. 7: renewal of Jabhat al-Nusra's official account on Twitter and a word to the supporters], al-Manara al-Bayda' Media Company, posted on 31 December 2013, https://justpaste.it/dyj8 (accessed on 19 September 2018).

26. Like supporters, members of Jabhat al-Nusra were also prohibited from speaking in the name of the group without authorization. In January 2015, Jabhat al-Nusra acknowledged the "important role played by social media platforms in the jihad arenas in general, and in the Levant arena in particular." However, the group's policies forbade its members to speak in its name. Infringement of these policies could result in trial and exclusion. In recent times, the statement continued, several members were expelled for this reason. Jabhat alNusra, Bayan i'lami raqm (11) [Media statement no. 11], al-Manara al-Bayda' Media Company, posted on 20 January 2015, https://justpaste.it/j002 (accessed on 19 September 2018).

27. Jabhat al-Nusra, Bayan i'lami raqm (5): shukr wa-i'tidhar [Media statement no. 5: thanks and apologies], al-Manara al-Bayda' Media Company, posted on 13 February 2013 at https://justpaste.it/1ywj (accessed on 19 September 2018).

28. Series of tweets on Himam News Agencies Twitter account (@Hemm_Agency), 7 July 2013.

29. AQAP created Ansar al-Shari'a in 2011 to operate and propagate in Yemen's tribal society. Abandoning the elitist quasi-jurisprudential rhetoric of Al Qaeda in favor of a more populist message, it created its own media outlets, including Madad News Agency, and produced propaganda aimed at Yemen's Sunni tribesmen. Christopher Swift, "Arc of Convergance: AQAP, Ansar al-Shari'a and the struggle for Yemen," CTC Sentinel 5, no. 6 (June 2012), 1-6.

30. Tweet on Jabhat al-Nusra's official Twitter account (@JabhtAnNusrah), 30 January 2014.

31. Its last known posting was “video report no. 94," posted on 27 August 2014.

32. Islamic State in Iraq and the Levant, Tanwih muhimm [Importance notice], posted on 17 August 2013, https://justpaste.it/3m0p (accessed on 19 September 2018). The group stressed this point again in an October 2013 statement. Islamic State in Iraq and the Levant, Tanwih muhimm hawla wasa'il al-i'lam [Important notice concerning the media], posted on 15 October 2013, https://justpaste.it/dcvp (accessed on 19 September 2018). By early 2014, at the latest, ISIL had managed to control the Twitter activities at least of its foreign fighters in areas under its control. Jytte Klausen, "Tweeting the Jihad: Social Media Networks of Western Foreign Fighters in Syria and Iraq," Studies in Conflict \& Terrorism 38, no. 1 (2015), 1-22.

33. Al-I'tisam Media video Dakk al-husun [The destruction of forteresses], dated 21 February 2013, posted at Ansar al-Mujahidin Arabic forum (www.as-ansar.com/vb/showthread. php? $\mathrm{p}=502781$ ) on 8 March 2013 (accessed on 19 September 2018).

34. The first installment of the series was published on 7 August 2013. The last known installment was no. 50, published on 3 March 2014. After this, al-I'tisam Media continued publishing videos, partially with extremely graphic content, until April 2015, after which it disappeared. Al-I'tisam Media's "Windows onto the land of epic battles" series was complemented by another series of videos, "Messages from the land of epic battles" (rasa'il min ard al-malahim), issued by ISI/ISIL's central media outlet al-Furqan Media also between August 2013 and March 2014.

35. Weimann, "Between the Arab Revolutions and the Islamic State's Caliphate," 133.

36. Jabhat al-Nusra, Bayan i'lami raqm (10): hawla rad' al-mufsidin [Media statement no. 10: on containing those who spread corruption], al-Manara al-Bayda' Media Company, posted on 21 July 2014, https://justpaste.it/gbni (accessed on 19 September 2018).

37. Jabhat al-Nusra, Bayan i'lami raqm (8) [Media statement no. 8], al-Manara al-Bayda' Media Company, posted on 4 April 2014, https://justpaste.it/ez7h (accessed on 19 September 2018).

38. Tweet on Jabhat al-Nusra’s official Twitter account (@JabhtAnNusrah), 9 July 2014. 
39. Lorenzo Franceschi-Bicchierai, "Twitter is Suspending Accounts that Post Images of Journalist's Beheading," Mashable, 20 August 2014, http://mashable.com/2014/08/20/twittersuspends-accounts-james-foley-beheading-execution (accessed on 19 September 2018). See also Prucha, "IS and the Jihadist Information Highway," 51.

40. Europol, Terrorism Situation and Trend Report (TE-SAT), 2016, 16.

41. Bayan nash wa tawdih [Statement of advice and clarification], Ansar al-Mujahidin Network, posted on 26 September 2013 at https://justpaste.it/d7ah (accessed on 19 September 2018).

42. The English Ansar al-Mujahidin forum ceased activities in June 2015, posting a notice on its homepage, which stated that they henceforth aimed to build "the best possible media platform in support of our mujahideen brothers" in Syria. "AMEF Says It Has Shut Down In Order To Provide Media Services For Mujahideen In Syria," MEMRI, 18 June 2015, http://cjlab.memri.org/lab-projects/tracking-jihadi-terrorist-use-of-social-media/amef-says-it-hasshut-down-to-instead-work-on-providing-media-services-for-the-mujahideen-in-syria (accessed on 19 September 2018).

43. Shumukh al-Islam Network statement, posted on 5 January 2014, https://justpaste.it/e00s (accessed on 19 September 2018).

44. Shumukh al-Islam Network statement, posted on 10 March 2014, https://justpaste.it/ep1k (accessed on 19 September 2018).

45. Jabhat al-Nusra, Bayan i'lami raqm (8) [Media statement no. 8], al-Manara al-Bayda' Media Company, posted on 4 April 2014, https://justpaste.it/ez7h (accessed on 19 September 2018).

46. For several weeks following the dispute between al-Baghdadi and al-Jawlani in early April 2013, Jabhat al-Nusra suspended its continued release of official statements, apparently awaiting the decision by the Al Qaeda leader. Statement 297 appeared on 8 April 2013, with statement 298 being issued only on 14 June 2013.

47. Shumukh al-Islam statement, posted on 30 April 2014, https://justpaste.it/facf (accessed on 19 September 2018).

48. Ahl al-hall wal-aqd (lit. "those who loose and bind") is a traditional term referring to people of authority, in particular those who would be entitled to elect the caliph.

49. Bayan intilaq mu'assasat al-tahaya lil-i'lam [Statement on the launch of al-Tahaya Media Company], al-Tahaya Media Company, 7 April 2014, https://archive.org/details/tahaya_byan (accessed on 19 September 2018).

50. A collection of al-Tahaya documents uploaded to the Internet Archive in November 2015 contains 478 documents. See https://archive.org/details/tayaha.archive.

51. The most important library of jihadist literature, Minbar al-Tawhid wal-Jihad, ceased activity around the same time. This made accessing jihadist literature online more difficult.

52. Bayan al-i'lan an intilaq al-jabha al-i'lamiyya li-nusrat al-dawla al-Islamiyya [Statement announcing the launch of the Media Front for the Support of the Islamic State], 25 October 2014.

53. Europol, Terrorism Situation and Trend Report (TE-SAT) 2017, 30.

54. Also the al-Fida' Islamic Network continues online. It has remained committed to Al Qaeda and accepts new registrations.

55. Prucha, "IS and the Jihadist Information Highway," 51. In addition to networking and evading countermeasures, IS saw operational benefits in the move to Telegram, including encrypted communication and protection against cyber-attacks. Ahmad Shehabat et al., "Encrypted Jihad: Investigating the Role of Telegram App in Lone Wolf Attacks in the West," Journal of Strategic Security 10, no. 3 (2017), 26-53.

56. Based on a sample from early 2017, it was found that other jihadist groups are subject to much lower levels of disruption by Twitter compared to IS accounts. Maura Conway et al., Disrupting Daesh. 